JIA (Jurnal Ilmiah Akuntansi) • Vol. 6, No. 1, Hal: 136-162 • Juni 2021 $\triangle$ ]

\title{
Determinan Tax Avoidance: Bukti Empiris pada Perusahaan Publik di Indonesia
}

\author{
Sumartono*, Indah Wahyu Tri Puspitasari \\ Universitas Yapis Papua, Jl. Dr. Samratulangi No. 11 Dok. V Atas Jayapura Utara, \\ Papua, Indonesia \\ *(sumartono@uniyap.ac.id)
}

\author{
Riwayat Artikel: \\ Tanggal diajukan: \\ 14 Oktober 2020 \\ Tanggal diterima: \\ 5 Juni 2021 \\ Tanggal dipublikasi daring: \\ 25 Juni 2021
}

\begin{abstract}
ABSTRAK
Penelitian ini bertujuan untuk menguji dan menganalisis variabel yang mempengaruhi perusahaan untuk melakukan upaya tax avoidance, seperti variabel Profitabilitas, leverage, ukuran perusahaan, komite audit dan karakater eksekutif berdasarkan data empiris yang relevan. Analisis penelitian pada sampel perusahaan manufaktur yang listing di Bursa Efek Indonesia (BEI) periode tahun 2014-2019 yang mendukung hipotesis kami. Dengan jumlah observasi yang diamati sebanyak 55 perusahaan. Hasil penelitian menunjukan bahwa tiga variabel mempunyai pengaruh positif signifikan yaitu variabel Leverage (DAR), Komite Audit (KA), dan Karakteristik eksekutif (KE), kemudian satu variabel lainnya mempunyai pengaruh negatif signifikan yaitu variabel Profitabilitas (ROA), sedangkan variabel terakhir tidak memiliki pengaruh terhadap tax avoidance yaitu variabel Ukuran perusahaan (SIZE) terhadap tax avoidance. Artikel ini menambah studi tentang pengaruh profitabilitas, leverage, ukuran perusahaan, komite audit, dan karakteristik eksekutif terhadap tax avoidance dan memiliki implikasi bagi manajemen perusahaan dan pembuat kebijakan.
\end{abstract}

leverage; profitabilitas; tax
avoidance; ukuran perusahaan

\section{Pengutipan:}

Sumartono \& Puspitasari, Indah Wahyu Tri. (2021). Determinan Tax Avoidance: Bukti Empiris pada Perusahaan Publik di Indonesia. JIA (Jurnal Ilmiah Akuntansi), Vol. 6, No. 1, Hal: 136-162.

Keywords: audit committee; company size; executive character; leverage; profitability; tax avoidance

\section{ABSTRACT}

This study aims to examine and analyze the variables that influence companies to undertake tax avoidance efforts, such as profitability, leverage, firm size, audit committee and executive character variables based on relevant empirical data. Research analysis on a sample of manufacturing companies listed on the Indonesia Stock Exchange (IDX) for the period 2014-2019 that supports our hypothesis. With the number of observations observed as many as 55 companies. The results showed that three variables had a significant positive effect, namely Leverage (DAR), Audit Committee $(K A)$, and Executive Characteristics (KE), then one other variable had a significant negative effect, namely the Profitability (ROA) variable, while the last variable did not have a significant negative effect. the effect on tax avoidance is the variable company size (SIZE) on tax avoidance. This article adds to the study of the effect of profitability, leverage, firm size, audit committee, and executive characteristics on tax avoidance and has implications for corporate management and policy makers. 


\section{PENDAHULUAN}

$\operatorname{Tax}$ avoidance

atau

Penghindaran pajak merupakan penghindaran saat terjadi fakta-fakta atas transaksi yang memang diakui akan tetapi telah diatur sedemikian rupa sehingga menghasilkan perlakuan pajak berbeda dari yang dimaksudkan oleh undang-undang yang relevan (Kay, 1980). Blaufus et al. (2016) menggambarkan tax avoidance merupakan aktivitas dalam batas-batas hukum dalam upaya merasionaliasi keputusan legalitas strategi pelaporan untuk mengurangi atau meminimalkan kewajiban pajak dengan memanfaatkan celah-celah dalam ketentuan perpajakan.

Tax avoidance berbeda dengan penggelapan pajak (tax evasion). Tax avoidance dilakukan melalui cara dengan tidak melanggar hukum yang berlaku, melainkan hanya memanfaatkan kelemahan dari sisi aturan yang berlaku, seperti tidak adanya aturan atas suatu transaksi atau skema tertentu. Sedangkan, penggelapan pajak merupakan upaya yang dilakukan oleh wajib pajak dengan melanggar aturan pajak yang berlaku, seperti melaporkan penghasilan yang tidak sesuai dengan fakta (Putranti et al., 2015).

Dalam melakukan Tax avoidance terdapat beberapa cara yang dilakukan perusahaan seperti transfer pricing (mark up) atau menurunkan harga (mark down). Selain itu fasilitas fiskal juga dimanfaatkan seperti tax allowance yaitu strategi perusahaan dalam upaya mengurangi pajak untuk menghindari pembayaran pajak (Afriyanti et al., 2019). Selain itu Hossain (2012) mengungkapkan beberapa cara perusahaan dalam melakukan Tax avoidance diantaranya yaitu dengan menampakkan laba dari aktivitas operasional sebagai laba dari modal sehingga mengurangi laba bersih dan utang pajak dari perusahaan tersebut, mengakui pembelanjaan modal sebagai pembelanjaan opersional, dan membebankan yang sama terhadap laba bersih sehingga dapat mengurangi utang pajak perusahaan, membebankan biaya personal sebagai biaya bisnis perusahaan sehingga mengurangi laba bersih, membebankan depresiasi produksi yang berlebihan di bawah nilai penutupan peralatan sehingga mengurangi laba kena pajak, dan mencatat pembuangan yang berlebihan dari bahan baku dalam industri manufaktur sehingga mengurangi laba kena pajak

PT Adaro misalnya, berdasarkan laporan Global Witness, Perusahaan tersebut telah melakukan tax avoidance dengan skema transfer 
pricing melalui anak perusahaanya yang berada di Singapura, lebih lanjut Global Witness mengatakan dalam laporannya bahwa PT. Adaro diindikasikan melarikan pendapatan dan labanya ke luar negeri sehingga dapat menekan kewajiban pajak yang dibayarkan kepada Pemerintah Indonesia lebih rendah dari seharusnya dengan nilai \$125 Juta (Tirto.id, 2019), selain itu CNN Indonesia (2016) melaporakan bahwa Direktorat Jenderal Pajak telah melakukan penyelidikan terhadap 2.000 Perusahaan multinasional yang terindikasi melakukan tax avoidance, kemudian sebuah Lembaga Tax Justice Network Juga melaporkan bahwa perusahaan tembakau milik British American Tobacco (BAT) telah melakukan tax avoidance di Indonesia melalui PT. Bentoel Internasional Investama yang berdampak terhadap kerugian negara hingga mencapai US\$ 14 juta per tahun (www.kontan.co.id, 2019).

Dari kasus-kasus yang dilakukan perusahaan tersebut atas upaya tax avoidance berimplikasi terhadap risiko penerimaan kas negara, sehingga akan mengurangi potensi pendapatan negara melalui sektor pajak, padahal sumber dana yang diperoleh untuk membiayai pembangunan sebagian besar berasal dari sektor pajak. Hal ini dibuktikan dengan penerimaan negara tahun 2019 dari sektor pajak hingga mencapai 1786,40 triliun atau memberikan kontribusi sebesar $82,50 \%$ dari total penerimaan selain Penerimaan Negara Bukan Pajak (PNBP) dan Hibah tahun 2019, ini berarti bahwa Penerimaan pajak memiliki peran utama guna mendukung pembangunan nasional (Kementerian Keuangan Republik Indonesia, 2019).

Penelitian ini bertujuan untuk menganalisis beberapa variabel yang mempengaruhi tax avoidance yaitu variabel Profitablitas, karena profitabilitas dianggap salah satu indikator pengukur kinerja perusahaan, Sehinga perusahaan yang memiliki profitabilitas yang lebih baik serta perusahaan yang memiliki nilai kompensasi rugi fiskal yang lebih sedikit terlihat memiliki nilai effective tax rates (ETRs) yang lebih tinggi. Menurut Anderson \& Reeb, (2003) Profitabilitas merupakan gambaran kinerja keuangan, semakin tinggi profitabilitas perusahaan maka semakin tinggi laba bersih yang dihasilkan dan diikuti dengan meningkatnya beban pajak penghasilan sehingga kecendrungan Tax avoidance akan meningkat sebagaimana mengacu kepada teori agency diamana para agen memiliki kepentingan untuk para pemilik 
dengan upaya untuk meningkatkan laba perusahaan. Penelitian Pitaloka \& Merkusiwati (2019), Handayani (2018), Syuhada dkk. (2019), dan Susanti (2018) menemukan profitabilitas berpengaruh terhadap tax avoidance, sedangkan Budiasih \& Amani (2019), Munawaroh \& Sari (2019), dan Tiala dkk. (2019) menemukan hasil yang berbeda yaitu profitabilitas suatu perusahaan tidak mempengaruhi perusahaan dalam melakukan tax avoidance

Keputusan pendanaan yang berindikasi dalam upaya melakukan tax avoidance adalah keputusan leverage. Leverage merupakan struktur hutang yang digunakan perusahaan dalam melakukan pembiayaan. Leverage diukur dengan membandingkan total kewajiban perusahaan dengan total aktiva yang dimiliki perusahaan (Surbakti, 2012). Dalam pembiayaan hutang terdapat komponen biaya bunga atas pinjaman yang menjadi pengurang dalam penghasilan kena pajak. Oleh karena itu, laba perusahaan sebelum pajak yang menggunakan hutang sebagai sumber pendanaan mayoritas akan cenderung lebih kecil dibandingkan perusahaan yang mendanai mayoritas kegiatan operasionalnya dengan penerbitan saham. Hal tersebut tentunya dapat mengurangi kewajiban pajak perusahaan dan celah perusahaan dalam melakukan upaya Tindakan Tax avoidance. Dalam Penelitian yang dilakukan Pitaloka \& Merkusiwati (2019), Tiala dkk. (2019), dan Barli (2018) menemukan bahwa leverage berpengaruh terhadap tax avoidance. Namun hasil penelitian tersebut tidak sejalan dengan penelitian yang dilakukan Budiasih \& Amani (2019), Handayani (2018), dan Susanti (2018), yang menemukan bahwa leverage tidak berpengaruh terhadap tax avoidance.

Ukuran perusahaan dianggap dapat mempengaruhi keputusan sebuah perusahaan dalam memenuhi kewajiban pajaknya dan merupakan salah satu faktor yang dapat menyebabkan terjadinya tax avoidance. Pada umumnya ukuran perusahaan (organization size) dapat diartikan sebagai suatu perbandingan besar atau kecilnya suatu objek. ukuran perusahaan (size) berpengaruh positif terhadap tingkat tax avoidance dalam suatu perusahaan (Surbakti, 2012). sehingga semakin besar ukuran perusahaan, maka perusahaan semakin mampu dalam upaya untuk mengatur perpajakan dengan melakukan tax saving yang dapat berimplikasi terhadap tax avoidance. Sebagaimana dalam penelitian Dewinta \& Setiawan, (2016) yang 
menyatakan bahwa Ukuran perusahaan berpengaruh positif terhadap Tax avoidance yang artinya bahwa semakin besar ukuran perusahaan maka akan semakin bersar upaya untuk melakukan Tax avoidance.

Selanjutnya, faktor lainnya adalah komite audit yang memiliki peran penting untuk terhubung dengan para pemegang saham. Tugas penting dari komite audit adalah memantau kebijakan yang dibuat perusahaan diantaranya dalam hal pelaporan keuangan. Oleh karena itu, kerja optimal dari peran komite audit perusahaan diharapkan mampu mengurangi perilaku upaya tax avoidance. Dalam penelitian yang dilakukan Pitaloka \& Merkusiwati (2019), Munawaroh \& Sari (2019), Tiala dkk. (2019), dan Mulyani dkk. (2018) menemukan bahwa komite audit berpengaruh terhadap tax avoidance. Namun penelitian yang dilakukan Syuhada dkk. (2019) menemukan hasil yang berbeda bahwa komite audit tidak berpengaruh terhadap tax avoidance.

Faktor terakhir adalah karakteristik eksekutif, diamana para eksekutif dianggap mempunyai peran dalam proses upaya melakukan Tax avoidance (Dyreng et al., 2010). Dengan pertimbangan kemungkinan bahwa Para eksekutif puncak secara individu ataupun sebagian bertanggung jawab atas variasi tax avoidance dalam sebuah perusahaan. Pada dasarnya, upaya tax avoidance yang dilakukan perusahaan tertentu akan berbeda tergantung kepada apakah itu dijalankan oleh Eksekutif A ataupun Eksekutif B. karena Secara Individu para Eksekutif memiliki karekteristik yang berbeda. Dalam Penelitian yang dilakukan Pitaloka \& Merkusiwati (2019) menemukan bahwa karakter eksekutif berpengaruh terhadap tax avoidance. Namun penelitian ini bertentangan dengan Fitria (2018) yang menemukan bahwa karakter eksekutif tidak berpengaruh terhadap tax avoidance.

Dari beberapa penelitian yang dilakukan peneliti sebelumnya, menunjukan hasil penelitian yang berbeda dari beberapa variabel yang diteliti, sehingga dianggap perlu untuk di lakukan penelitian kembali terhadap beberapa variabel penelitian, Dalam penelitian ini analisis regeresi data panel digunakan sebagai alat analisis, Peneliti juga menambahkan satu variabel penelitian yaitu Ukuran perusahaan, dengan alasan semakin besar ukuran perusahaan semakin meningkat upaya perusahaan untuk melakukan pengindaran pajak, dikarenakan didukung oleh tenagatenaga profesional dibidang hukum 
maupun perpajakan, kemudian peneliti juga memperluas objek dan sampel penelitian yang merupakan keterbatasan peneliti sebelumnya dari rata-rata 4 tahun periode pengamatan menjadi 6 tahun yaitu 2014-2019. Selain itu bahwa prilaku tax avoidance merupakan usaha maupun upaya yang akan tetap dilakukan sepanjang wajib pajak menemukan celah-celah kekurangan yang berhubungan dengan peraturan dan skema peraturan perpajakan yang berlaku.

Dari uraian yang telah dikemukakan, maka diperoleh rumusan masalah penelitian, yaitu: Apakah Profitabilitas, Leverage, Ukuran Perusahaan, Komite audit dan Karakteristik Eksekutif secara parsial dapat mempengaruhi upaya perusahaan untuk melakukan tax avoidance? Penelitian ini diharapkan dapat memberikan kontribusi terhadap wajib pajak badan maupun bagi Pemerintah. Seperti dapat menambah tingkat kepatuhan perusahaan sebagai wajib pajak badan dalam upaya melaksanakan kewajibannya membayar pajak. Selain itu Perusahaan diharapkan dapat lebih bijak dalam mengambil keputusan mengenai perencanaan perpajakan, agar terhindar dari praktik-praktik yang merugikan negara, selain itu juga dapat membayar pajak dengan patuh sesuai ketentuan umum perpajakan dan Tata cara perpajakan yang berlaku di Negara Kesatuan Republik Indonesia. dan dapat memberikan informasi relevan sekaligus masukan serta evaluasi terutama kepada pemerintah agar dapat lebih dekat dan intens memantau perusahaan-perusahaan dalam memenuhi kewajiban pajaknya di Indonesia, untuk lebih memperhatikan beberapa faktor potensial yang mempengaruhi upaya praktik Tax avoidance yang dilakukan wajib pajak badan dalam melakukan perencanaan pajak yang memberikan dampak dan risiko terhadap penerimaan kas negara.

\section{TELAAH LITERATUR DAN PERUMUSAN HIPOTESIS \\ Teori Agency}

$$
\text { Jensen \& Meckling }
$$

mempopulerkan Teori Agencynya, yang menyatakan bahwa hubungan keagenan sebagai kontrak di mana satu atau lebih principal melibatkan agen untuk melakukan beberapa layanan atas nama mereka dan ada kepentingan yang berbeda antara principal dan agen, disatu sisi agen menginginkan nilai perusahaan yang tinggi sehingga menarik minat investor agar laba perusahaan bertambah dengan melakukan upaya Tax avoidance. Namun selain itu ada 
alasan lain yang kuat untuk percaya bahwa agen tidak selalu bertindak untuk kepentingan terbaik prinsipal.

\section{Penghindaran Pajak (Tax avoidance)}

Dyreng et al., (2008), mendefinisikan tax avoidance secara luas yaitu mencakup upaya apa pun yang relatif mengurangi pajak perusahaan atas pendapatan akuntansi sebelum pajak. atau hanya sebagian jumlah pajak yang dibayarkan dengan tidak menimbulkan restitusi pajak di kemudian hari (Mangoting, 1999). Sedangkan Blaufus dkk., (2016). mendefiniskan tax avoidance sebagai upaya tax avoidance yang dilakukan secara legal dalam upaya merasionaliasi keputusan legalitas strategi pelaporan untuk mengurangi atau meminimalkan kewajiban pajak dengan memanfaatkan celah-celah dalam ketentuan perpajakan. sehingga aman bagi wajib pajak karena tidak bertentangan dengan ketentuan perpajakan yang berlaku, dimana metode dan teknik yang digunakan cenderung memanfaatkan kelemahan-kelemahan (grey area) yang terdapat dalam undang-undang dan peraturan perpajakan dalam upaya mengurangi beban pajak yang akan dibayarkan perusahaan, meskipun demikian pemerintah tidak menghendaki perusahaan melakukan tax avoidance dikarenakan dapat mengurangi penerimaan negara.

Stiglitz, (1985) membedakan tiga prinsip dasar penghindaran pajak (tax avoidance) dalam pajak penghasilan: penundaan pajak, arbitrase pajak di seluruh wajib pajak yang menghadapi tanda kurang pajak yang berbeda (atau wajib pajak sama yang menghadapi tarif pajak marjinal yang berbeda pada waktu yang berbeda), dan arbitrase pajak di seluruh aliran pendapatan yang dihadapi perlakuan pajak yang berbeda.

\section{Pengaruh Profitabilitas terhadap Tax Avoidance}

Kemampuan perusahaan menghasilkan laba merupakan fokus utama prestasi perusahaan. Laba menjadi indikator kemampuan perusahaan dalam memenuhi kewajiban kepada kreditur, investor, bahkan pemerintah serta merupakan bagian dalam proses penciptaan nilai perusahaan berkaitan dengan prospek perusahaan di masa depan (Andriyanto et al., 2015)

Berdasarkan teori agensi, dimana principal menginginkan agent bekerja untuk kepentingan principal. Disatu sisi para agen menginginkan nilai perusahaan yang tinggi untuk menarik minat para investor dengan 
cara melakukan Tax avoidance, sehingga laba yang diperoleh perusahaan semakin bertambah.

Undang-Undang No. 36 Tahun 2008 Pasal 1, Tentang Pajak Penghasilan dijelaskan bahwa penghasilan yang diterima oleh subjek pajak akan dikenakan pajak penghasilan. Besar kecilnya pajak yang harus dibayarkan wajib pajak berbanding lurus dengan besar kecilnya penghasilan yang peroleh wajib pajak dalam suatu periode, sehingga semakin tinggi profitability perusahaan maka semakin tinggi pajak yang harus dibayarkan sedangkan perusahaan yang memiliki tingkat keuntungan yang rendah atau bahkan mengalami rugi akan membayar pajak lebih sedikit atau tidak sama sekali (Putri, 2017).

Mayoritas studi penelitian terdahulu yang mengukur pengaruh profitabiltas terhadap Tax avoidance menemukan hasil positif antara profitabilitas dan tax avoidance (Dogan, 2013), Studi yang dilakukan Pitaloka \& Merkusiwati (2019), Handayani (2018), Syuhada dkk. (2019), dan Susanti (2018) menunjukkan bahwa profitabilitas berpengaruh terhadap tax avoidance. Sedangkan tidak sedikit penelitian terdahulu seperti Budiasih \& Amani (2019), Munawaroh \& Sari (2019), dan Tiala dkk. (2019) menunjukkan hasil berbeda yaitu profitabilitas perusahaan tidak mempengaruhi perusahaan dalam melakukan Tax avoidance.

Pitaloka \& Merkusiwati (2019), menyatakan bahwa Perusahaan yang memiliki laba yang besar akan sangat mudah untuk memanfaatkan celah dalam pengelolaan beban pajaknya. Dimana Laba yang tinggi akan menyebabkan semakin tingginya beban pajak yang harus dibayar perusahaan sehingga perusahaan cenderung melakukan upaya praktik tax avoidance untuk mengurangi beban pajaknya, sehingga hipotesis penelitian dapat dikemukakan, sebagai berikut:

$\mathrm{H}_{1}$ : Profitabilitas berpengaruh positif terhadap tax avoidance

\section{Pengaruh Leverage terhadap Tax avoidance}

Leverage merupakan Rasio keuangan yang dapat menggambarkan sejauh mana perusahaan dibiayai melalui oleh hutang untuk membiayai aktiva perusahaan. leverage dapat mempengaruhi besarnya pajak yang dibayarkan perusahaan karena dengan adanya hutang maka akan timbul beban bunga yang dapat menjadi pengurang pajak terutang perusahaan. 
Leverage digunakan untuk mengukur kemampuan perusahaan untuk membayar seluruh kewajiban baik jangka pendek maupun jangka panjang. Penggunaan hutang dalam membiayai kegiatan operasional perusahaan akan menimbulkan bunga, dan biaya bunga tersebut dapat dikurangkan dari pajak (Barli, 2018).

Dalam teori agensi, agent ditugaskan oleh principal untuk mengelola perusahaan. Agent meminjam ke bank dengan nominal pinjaman yang cukup besar sehingga timbul bunga pinjaman yang semakin besar pula, bunga pinjaman tersebut dibebankan dalam laporan keuangan Fiskal Agen, akan tetapi pinjaman tersebut bukan untuk menambah modal agen sehingga pendapatan tidak tumbuh sehinga menjadikan laba tidak bertambah. Sehingga hutang dapat menyebabkan penurunan pajak dikarenakan ada beban bunga yang timbul dari hutang yang dimiliki oleh perusahaan.

Menurut (Undang-Undang Nomor 36 Tahun 2008 Tentang Perubahan Keempat Atas UndangUndang Nomor 7 Tahun 1983 Tentang Pajak Penghasilan, 2008) melalui Undang-Undang No. 36 Tahun 2008 Pasal 6 ayat 1 huruf a angka 3 menyatakan bahwa bunga pinjaman merupakan biaya yang dapat dikurangkan (deductible expense) terhadap penghasilan kena pajak . Dengan adanya dukungan peraturan perpajakan tersebut maka akan mengakibatkan laba kena pajak perusahaan berkurang, dengan Berkurangnya laba kena pajak pada akhirnya akan mengurangi jumlah pajak yang harus dibayar perusahaan, dengan demikian perusahaan yang memiliki hutang tinggi akan mendapatkan insentif pajak yang dapat digunakan perusahaan untuk meminimalkan pajak yang harus dibayarkan dengan cara menambah sumber pendanaan perusahaan melalui hutang. Sehingga Perusahaan-perusahaan dengan tingkat profitabilitas tinggi tentu akan berusaha untuk mengurangi pajaknya dengan cara meningkatkan rasio hutangnya, adanya tambahan hutang tersebut akan berimplikasi mengurangi beban pajak.

$$
\text { Penelitian yang dilakukan }
$$
Pitaloka \& Merkusiwati (2019), Tiala dkk. (2019), dan Barli (2018) memberikan bukti empiris bahwa adanya pengaruh positif leverage terhadap tax avoidance yang menyatakan bahwa perusahaan memiliki nilai rasio leverage yang tinggi, dengan tingginya penggunaan utang yang dimiliki oleh perusahaan, maka semakin akan besar beban bunga yang harus dibayarkan oleh 
perusahaan, sehingga dapat mengindikasikan bahwa perusahaan akan melakukan tindakan tax avoidance. Sehingga hipotesis dapat dikemukakan sebagai berikut:

$\mathrm{H}_{2}$ : Leverage berpengaruh positif terhadap Tax avoidance

\section{Pengaruh Ukuran Perusahaan terhadap Tax avoidance}

Ukuran perusahaan adalah gambaran dari besar kecilnya suatu perusahaan (Brigham \& Houston, 2019), perusahaan yang mempunyai laba Laba yang besar dan stabil akan cenderung mendorong perusahaan untuk melakukan praktik penghindaran pajak (tax avoidance) dikarenakan laba yang besar akan menyebabkan beban pajak yang besar pula.

Berdasarkan Peraturan

Pemerintah Nomor 77 Tahun 2013, tentang Penurunan Tarif Pajak Penghasilan Bagi Wajib Pajak Badan Dalam Negeri yang Berbentuk Perseroan Terbuka yang ditetapkan pada tanggal 21 November 2013 dan berlaku sejak tahun pajak 2013 berupa fasilitas penurunan tarif pajak. Perusahaan yang memanfaatkan pengurangan tarif pajak dengan tujuan memperkecil beban pajak perusahaan, maka perusahaan tersebut dianggap telah melakukan tax avoidance (Putri \&
Suryarini, 2017). Dengan demikian merujuk pada teori agensi, bahwa sumber daya yang dimiliki oleh perusahaan dapat digunakan oleh agent untuk memaksimalkan kompensasi kinerja agent, dengan menekan beban pajak perusahaan untuk memaksimalkan kinerja perusahaan (Dewinta \& Setiawan, 2016).

Dalam penelitian yang dilakukan Budiasih \& Amani (2019), Fitria (2018), dan Handayani (2018) memberikan bukti empiris bahwa adanya pengaruh ukuran perusahaan terhadap tax avoidance. Budiasih \& Amani (2019) menyatakan bahwa semakin besar ukuran perusahaannya, maka transaksi yang dilakukan akan semakin kompleks. Jadi hal itu memungkinkan perusahaan untuk memanfaatkan celah-celah yang ada untuk melakukan tindakan tax avoidance dari setiap transaksi yang dilakukan perusahaan. Sehingga hipotesis dapat dirumuskan sebagai berikut:

$\mathrm{H}_{3}$ : Ukuran perusahaan berpengaruh positif terhadap Tax avoidance

\section{Pengaruh Komite Audit terhadap Tax avoidance}

Komite audit merupakan salah satu elemen dalam tata kelola perusahaan (corporate governance). Dengan penggunaan wewenang yang 
dilakukan dengan tepat, maka komite audit dapat mencegah atau mendeteksi lebih dini perilaku atau tindakan menyimpang yang berhubungan dengan laporan keuangan entitas (Munawaroh \& Sari, 2019).

Berdasarkan Peraturan Otoritas Jasa Keuangan Nomor 55 /POJK.04/2015 Tentang Pembentukan Dan Pedoman Pelaksanaan Kerja Komite Audit Pasal 1 , komite audit adalah komite yang dibentuk oleh dewan komisaris dan bertanggung jawab kepada dewan komisaris dalam membantu melaksanakan tugas dan fungsi dewan komisaris. Struktur komite audit berdasarkan pasal 4 yaitu mempunyai anggota paling sedikit 3 (tiga) orang anggota yang berasal dari komisaris independen dan pihak luar emiten atau perusahaan publik.

Lebih lanjut (Puspita \& Harto, 2014) melalui artikelnya mengatakan bahwa Komite audit merupakan alat yang efektif untuk melakukan mekanisme pengawasan, sehingga dapat mengurangi biaya agensi dan meningkatkan kualitas pengungkapan perusahaan. Komite Audit memiliki tugas untuk dilakukan pemeriksaan tentang komposisi pelaporan keuangan dan untuk melakukan pengendalian intern dalam sebuah perusahaan (Sulistiyanti \& Saputra, 2020).

Dalam praktiknya hubungan antara agent dan principal, terdapat asimetri informasi dikarenakan agent lebih banyak mengetahui informasi mengenai perusahaan dibandingkan dengan principal. Oleh karena itu untuk mengantisipasi hal tersebut diperlukan komite audit yang mempunyai peran dan tugas untuk mengawasi kinerja agent (manajemen) agar bertindak sesuai dengan harapan principal. (Diantari \& Ulupui, 2016) menyatakan bahwa komite audit yang bertugas melakukan pengawasan dalam penyusunan laporan keuangan perusahaan dapat mendeteksi dan mencegah kecurangan yang dilakukan agent (manajemen). Dengan demikian Perusahaan yang memiliki komite audit akan lebih bertanggung jawab dan terbuka dalam pengungkapan dan penyajian laporan keuangan entitas, serta diharapkan bahwa komite audit yang ada pada perusahaan dapat menjalankan tugas dan wewenangnya dalam melakukan pengawasan terhadap perusahaan.

Munawaroh \& Sari (2019) menyatakan bahwa komite audit suatu perusahaan mampu mengoptimalkan wewenang dan peran monitoring-nya untuk mengendalikan tindakan tax avoidance yang 
dilakukan manajemen perusahaan, Sehingga semakin banyak jumlah komite audit (meskipun jumlahnya dibatasi oleh peraturan pasar modal), faktanya mampu meminimalisasi tindakan Tax avoidance.

Penelitian Pitaloka \& Merkusiwati (2019), Munawaroh \& Sari (2019), Tiala dkk. (2019), dan Mulyani dkk. (2018) menunjukkan bukti empiris bahwa komite audit berpengaruh terhadap tax avoidance. Dari paparan diatas dapat dikemukakan Hipotesis sebagai berikut:

$\mathrm{H}_{4}$ : Komite audit berpengaruh negative terhadap tax avoidance.

\section{Pengaruh Karakter Eksekutif terhadap Tax avoidance}

Eksekutif merupakan pimpinan perusahaan secara langsung maupun tidak langsung memiliki pengaruh terhadap keputusan yang diambil perusahaan, termasuk keputusan tax avoidance yang dilakukan perusahaan (Hanafi \& Harto, 2014). Pimpinan puncak perusahaan sebagai pengambil kebijakan perusahaan tentu memiliki karakter yang berbeda-beda. Seorang pemimpin perusahaan dapat memiliki karakter yang risk taker atau risk averse, karakter tersebut dapat tercermin dari besar kecilnya risiko perusahaan (Dewi \& Jati, 2014), dimana Risk averse merupakan karakteristik eksekutif yang kurang menyukai risiko dalam mengambil keputusan bisnis, eksekutif ini akan lebih cenderung memilih keputusan melalui risiko yang lebih kecil (Carolina et al., 2014). Namun terdapat bukti beberapa eksekutif memandang bahwa risiko praktik minimalisasi pajak sebagai cara yang dapat diterima dalam menjalankan melakukan operasi bisnis dan berusaha menerapkan secara aktif strategi mengurangi beban pajak perusahaan (Hasan et al., 2017).

Penelitian yang dilakukan Afriyanti dkk. (2019) dan Pitaloka \& Merkusiwati (2019) menunjukkan bukti empiris bahwa karakter eksekutif berpengaruh positif terhadap tax avoidance. Dari paparan diatas dapat dikemukakan Hipotesis sebagai berikut:

$\mathrm{H}_{5}$ : Karakter eksekutif berpengaruh positif terhadap Tax avoidance

\section{METODE}

Penelitian ini menggunakan data sekunder berupa laporan keuangan tahunan, Data diperoleh melalui laman situs www.idx.co.id. Jenis data yang digunakan yaitu data panel yang merupakan gabungan antara data runtut waktu (time series) dan data silang (cross section). 
Populasi dalam penelitian ini yaitu perusahaan manufaktur yang listing di Bursa Efek Indonesia periode tahun 2014 s.d 2019, Sampel penelitian diambil menggunakan teknik purposive sampling. Adapun kriteria dalam penentuan sampel adalah sebagai berikut: (1) Perusahaan Manufaktur yang secara konsisten listing di BEI periode 20142019. (2) Perusahaan Manufaktur yang menerbitkan laporan keuangan secara lengkap selama periode pengamatan (3) Perusahaan Manufaktur yang menerbitkan laporan keuangannya dalam bentuk rupiah. (4) Perusahaan Manufaktur yang memiliki laba positif selama periode pengamatan. Dari kreteria sampel tersebut, maka jumlah sampel perusahaan manufaktur yang memenuhi kriteria sebanyak 55 perusahaan (lihat lampiran).

\section{Definisi Operasional Variabel Penelitian}

Penelitian ini terdiri dari variabel Tax avoidance sebagai variabel Dependent dan Variabel Profitabilitas, Leverage, Ukuran Perusahaan, Komite Audit, dan Karakteristik Eksekutif Sebagai variabel Independent. Sebagaimana Operasional Variabelnya disajikan pada Tabel 1.
Tax avoidance

Praktik tax avoidance dapat diukur dengan Cash Effective Tax Rate (CETR). CETR diharapkan mampu mengidentifikasikan keagresifan perencanaan pajak (Tax Planning) perusahaan yang dilakukan dengan menggunakan perbedaan tetap maupun perbedaan temporer (Chen dkk, 2010). CETR dihitung menggunakan Rumus sebagai berikut:

\section{Cash Effective Tax Rate \\ (CETR) $=\frac{\text { Pembayaran Pajak }}{\text { Laba Sebelum Pajak }}$}

\section{Profitabilitas}

Rasio Profitabilitas memberikan gambaran terkait bagaimana cara perusahaan menggunakan dan memanfaatkan asset secara menguntungkan. Rasio ini juga memberikan ukuran tingkat efektifitas manajemen suatu perusahaan dalam menggunakan aset. Hal ini ditunjukkan oleh laba yang dihasilkan dari penjualan dan pendapatan investasi dan merupakan cerminan hasil akhir dari seluruh kebijakan keuangan dan keputusan operasi perusahaan (Brigham \& Houston, 2019). 
Tabel 1. Operasional Variabel Penelitian

\begin{tabular}{|c|c|c|c|c|}
\hline No & Variabel & Definisi & Pengukuran & Sumber \\
\hline 1 & $\begin{array}{l}\text { Tax } \\
\text { avoidance }\end{array}$ & $\begin{array}{l}\text { Praktik tax avoidance dapat diukur } \\
\text { dengan Cash Effective Tax Rate } \\
\text { (CETR). CETR diharapkan mampu } \\
\text { mengidentifikasikan keagresifan } \\
\text { perencanaan pajak (Tax Planning) } \\
\text { perusahaan yang dilakukan dengan } \\
\text { menggunakan perbedaan tetap } \\
\text { maupun perbedaan temporer }\end{array}$ & $\begin{array}{l}\text { Cash Effective Tax Rate (CETR) } \\
=(\text { Pembayaran Pajak)/(Laba } \\
\text { Sebelum Pajak) }\end{array}$ & $\begin{array}{l}\text { (Chen et al., } \\
\text { 2010). }\end{array}$ \\
\hline 2 & Profitabilitas & $\begin{array}{l}\text { Return on Assets (ROA) merupakan } \\
\text { salah satu rasio profitabilitas. ROA } \\
\text { digunakan untuk mengukur } \\
\text { kemampuan perusahaan dalam } \\
\text { menghasilkan laba berdasarkan } \\
\text { tingkat aset tertentu. Semakin } \\
\text { tinggi nilai ROA, maka semakin } \\
\text { besar juga laba yang diperoleh } \\
\text { perusahaann }\end{array}$ & $\begin{array}{l}\text { Return On Assets (ROA) = } \\
\text { (Earning After Tax)/(Total } \\
\text { Assets) x } 100 \%\end{array}$ & $\begin{array}{l}\text { (Brigham \& } \\
\text { Houston, } \\
\text { 2019). }\end{array}$ \\
\hline 3 & Leverage & $\begin{array}{l}\text { Leverage merupakan Rasio } \\
\text { keuangan yang dapat } \\
\text { menggambarkan sejauh mana } \\
\text { perusahaan dibiayai melalui oleh } \\
\text { hutang untuk membiayai aktiva } \\
\text { perusahaan }\end{array}$ & $\begin{array}{l}\text { Debt to Assets Ratio (DAR) = } \\
\text { (Total Liabilitas atau } \\
\text { Kewajiban)/(Total Aset) }\end{array}$ & $\begin{array}{l}\text { Susanti } \\
(2018)\end{array}$ \\
\hline 4 & $\begin{array}{l}\text { Ukuran } \\
\text { Perusahaan }\end{array}$ & $\begin{array}{l}\text { Ukuran perusahaan adalah } \\
\text { gambaran dari besar kecilnya } \\
\text { suatu perusahaan. }\end{array}$ & $\begin{array}{l}\text { Ukuran Perusahaan }=\text { Ln Total } \\
\text { Aktiva }\end{array}$ & (Lee, 2009) \\
\hline 5 & Komite Audit & $\begin{array}{l}\text { Komite audit adalah komite yang } \\
\text { dibentuk oleh dewan komisaris dan } \\
\text { bertanggung jawab kepada dewan } \\
\text { komisaris dalam membantu } \\
\text { melaksanakan tugas dan fungsi } \\
\text { dewan komisaris, Komite audit } \\
\text { memiliki peran utama utama untuk } \\
\text { mengawasi proses pelaporan } \\
\text { keuangan perusahaan, mereka } \\
\text { bertemu secara teratur dengan } \\
\text { auditor eksternal perusahaan dan } \\
\text { manajer keuangan perusahaan } \\
\text { untuk meninjau laporan keuangan } \\
\text { perusahaan, proses audit, dan } \\
\text { internal kontrol akuntansi }\end{array}$ & $\begin{array}{l}\text { Dalam studi ini variabel komite } \\
\text { audit di ukur dengan total } \\
\text { jumlah anggota komite audit } \\
\text { dalam satu perusahaan. }\end{array}$ & $\begin{array}{l}\text { (Hanum \& } \\
\text { Zulaika, 2013) }\end{array}$ \\
\hline 6 & $\begin{array}{l}\text { Karakteristik } \\
\text { Eksekutif }\end{array}$ & $\begin{array}{l}\text { Eksekutif merupakan pimpinan } \\
\text { perusahaan secara langsung } \\
\text { maupun tidak langsung memiliki } \\
\text { pengaruh terhadap keputusan yang } \\
\text { diambil perusahaan, termasuk } \\
\text { keputusan tax avoidance yang } \\
\text { dilakukan perusahaan. Pimpinan } \\
\text { puncak perusahaan sebagai } \\
\text { pengambil kebijakan perusahaan } \\
\text { tentu memiliki karakter yang } \\
\text { berbeda-beda. Seorang pemimpin } \\
\text { perusahaan dapat memiliki } \\
\text { karakter yang risk taker atau risk } \\
\text { averse dapat tercermin dari besar } \\
\text { kecilnya risiko perusahaan }\end{array}$ & $\begin{array}{l}R I S K=\sqrt{\Sigma}(E-1 / T \Sigma E) 2 /(T-1) \\
T t-1 T t-1 \\
\text { Note: } \\
\mathrm{E}=\text { EBITDA/Total aset } \\
\mathrm{T}=\text { Total Sampel } \mathrm{t}=\text { Tahun }\end{array}$ & $\begin{array}{l}\text { (Pitaloka \& } \\
\text { Merkusiawati, } \\
\text { 2019). }\end{array}$ \\
\hline
\end{tabular}




\begin{abstract}
Return on Assets (ROA) merupakan salah satu rasio profitabilitas. ROA digunakan untuk mengukur kemampuan perusahaan dalam menghasilkan laba berdasarkan tingkat aset tertentu. Semakin tinggi nilai ROA, maka semakin besar juga laba yang diperoleh perusahaann (Pitaloka \& Merkusiawati, 2019). yang dapat tejadi dikarenakan penggunaaan utang yang kecil dalam hal ini beban bunga yang rendah akan menyebabkan laba neto menjadi tinggi (Brigham \& Houston, 2019). Apabila perusahaan memiliki rasio profitabilitas yang tinggi, maka akan mempengaruhi besarnya pajak yang akan dibayarkan oleh perusahaan. ROA dihitung menggunakan Rumus sebagai berikut:
\end{abstract}

\section{Return On Assets (ROA) = $\frac{\text { Earning After Tax }}{\text { Total Assets }} \times 100 \%$}

Leverage

Leverage merupakan Rasio keuangan yang dapat menggambarkan sejauh mana perusahaan dibiayai melalui oleh hutang untuk membiayai aktiva perusahaan. leverage dapat mempengaruhi besarnya pajak yang dibayarkan perusahaan karena dengan adanya hutang maka akan timbul beban bunga yang dapat menjadi pengurang pajak terutang perusahaan. Adapun dalam penelitian ini tingkat leverage yang dimiliki suatu perusahaan dapat diukur menggunakan rasio Debt to Assets Ratio (DAR) yang merupakan rasio untuk mengukur perbandingan antara total utang dengan total aktiva. ROA dihitung menggunakan Rumus sebagai berikut:

\section{Debt to Assets Ratio (DAR) =}

$\underline{\text { Total Liabilitas atau Kewajiban }}$ Total Aset

\section{Ukuran Perusahaan}

Ukuran perusahaan adalah gambaran dari besar kecilnya suatu perusahaan (Brigham \& Houston, 2019), Mayoritas penelitian menggunakan total aset, total penjualan atau jumlah karyawan sebagai indikator ukuran perusahaan (Dogan, 2013). Dalam studi ini ukuran perusahaan diukur dengan menggunakan total asset yaitu nilai log asset, sama halnya dengan studi (Lee, 2009)

\section{Ukuran Perusahaan $=$ Ln Total}

\section{Aktiva}

\section{Komite Audit}

Komite audit memiliki peran utama utama untuk mengawasi proses pelaporan keuangan perusahaan, mereka bertemu secara teratur dengan auditor eksternal 
perusahaan dan manajer keuangan perusahaan untuk meninjau laporan keuangan perusahaan, proses audit, dan internal kontrol akuntansi (Klein, 2002).

Berdasarkan Peraturan Otoritas Jasa Keuangan Nomor 55 /POJK.04/2015 Tentang Pembentukan Dan Pedoman Pelaksanaan Kerja Komite Audit Pasal 1 , komite audit adalah komite yang dibentuk oleh dewan komisaris dan bertanggung jawab kepada dewan komisaris dalam membantu melaksanakan tugas dan fungsi dewan komisaris. Struktur komite audit berdasarkan pasal 4 yaitu mempunyai anggota paling sedikit 3 (tiga) orang anggota yang berasal dari komisaris independen dan pihak luar emiten atau perusahaan publik.

Komite audit dapat berfungsi secara independen jika dan hanya jika semua anggota bebas dari pengaruh manajerial. Sehingga komite audit merupakan salah satu bagian penting di perusahaan karena dapat menjembatani antara manajemen dengan pemilik usaha dengan cara mengawasi kinerja manajemen agar tidak terjadi penyimpangan sehingga dapat merugikan pemilik usaha (principal). dalam studi ini variabel komite audit di ukur dengan total jumlah anggota komite audit dalam satu perusahaan.

\section{Karakteristik Eksekutif}

Eksekutif merupakan pimpinan perusahaan secara langsung maupun tidak langsung memiliki pengaruh terhadap keputusan yang diambil perusahaan, termasuk keputusan tax avoidance yang dilakukan perusahaan (Hanafi \& Harto, 2014). Pimpinan puncak perusahaan sebagai pengambil kebijakan perusahaan tentu memiliki karakter yang berbedabeda. Seorang pemimpin perusahaan dapat memiliki karakter yang risk taker atau risk averse dapat tercermin dari besar kecilnya risiko perusahaan (Dewi \& Jati, 2014), dimana Risk averse merupakan karakteristik eksekutif yang kurang menyukai risiko dalam mengambil keputusan bisnis, eksekutif ini akan lebih cenderung memilih keputusan melalui risiko yang lebih kecil (Carolina dkk., 2014). Namun Beberapa eksekutif memandang bahwa risiko praktik minimalisasi pajak sebagai cara yang dapat diterima untuk melakukan operasi bisnis dan menerapkan strategi mengurangi beban pajak perusahaan (Hasan dkk., 2017)

Dalam Penelitian ini Risiko perusahaan dapat diukur dengan menghitung standar deviasi dari Earning Before Interest, Tax, Depreciation, and Amortization (EBITDA) dibagi total aset. Dengan 
Rumus risiko perusahaan sebagai berikut:

$$
R I S K=\sqrt{\Sigma}(E-1 / T \Sigma E) 2 /(T-1) T t-1 T t-1
$$

Keterangan:

$\mathrm{E}=\mathrm{EBITDA} /$ Total aset

$\mathrm{T}=$ Total Sampel $\quad \mathrm{t}=$ Tahun

\section{Teknis Analisis Data}

Penelitian ini menggunakan analisis regeresi data panel (Ghozali \& Ratmono, 2017), melalui pendekatan standar cross section dan time series dengan mengistimasi model penelitian yang tepat. Adapun persamaan Regresi data panel dalam penelitian ini sebagai berikut:

$$
\begin{aligned}
\mathrm{TA}_{i \mathrm{it}}=\mathrm{a} & +\beta_{1} \mathrm{ROA}_{\mathrm{it}}+\beta_{2} \mathrm{DAR}_{\mathrm{it}}+\beta_{3} \mathrm{SIZE}_{\mathrm{it}} \\
& +\beta_{4} \mathrm{KA}_{\mathrm{it}}+\beta_{5} \mathrm{KE}_{\mathrm{it}}+\mathrm{e}_{\mathrm{it}} \\
\mathrm{CAit}= & \text { Tax avoidance } \\
\mathrm{ROA}_{\mathrm{it}}= & \text { Profitabilitas } \\
\mathrm{DAR}_{\mathrm{it}}= & \text { Leverage } \\
\mathrm{SIZE}_{\mathrm{it}}= & \text { Ukuran Perusahaan } \\
\mathrm{KA}_{\mathrm{it}}= & \text { Komite Audit } \\
\mathrm{KE}_{\mathrm{it}}= & \text { Karakteristis Eksekutif } \\
\beta_{1}= & \text { Koefesien masing-masing } \\
\text { variabel } & (\mathrm{i}=1,2.3,4,5) \\
\mathrm{e}_{\mathrm{it}} \quad= & \text { Tingkat kesalahan (error term) } \\
\mathrm{i} \quad= & 1,2 \ldots . .55 \\
\mathrm{t} \quad= & 1,2,3,4,5,6
\end{aligned}
$$

Sebelum melakukan analisis
data panel, telebih dahulu
menentukan model yang tepat untuk
penelitian ini apakah common effect
model (CEM), Fixed effect Model
(FEM), random effect model (REM)
dengan melakukan Pengujian

terhadap model tersebut dengan beberapa tahap yaitu: Pertama Uji Chow untuk menentukan model yang terbaik antara CEM dan FEM, Kedua Uji Hausman untuk menentukan model yang terbaik antara FEM dan REM, dan yang Ketiga Uji Lagrange Multiplier untuk menentukan model yang terbaik antara REM dan CEM.

\section{HASIL DAN PEMBAHASAN \\ Estimasi Mode1}

Untuk menentukan model yang terbaik merupakan syarat dalam analisis data panel dengan melakukan tahapan analisis melalui estimasi model Common Effect (CEM), Fixed Effect (FEM), dan Random Effect (REM) dengan melakukan Dari hasil Uji Hausman yang disajikan pada tabel 4, diperoleh nilai chi-square sebesar 57.631 dan prob pada Cross-section random kurang dari alpha (a) $(0.0000<0.05)$, maka FEM lebih baik digunakan dari REM. Dari hasil kedua uji yang telah dilakukan baik Uji Chow maupun Uji Hauman menghasilkan FEM sebagai model terbaik sehingga tidak perlu lagi melakukan Uji Lagrange Multiplier dan Dengan demikian, dapat disimpulkan bahwa model digunakan dalam regresi data panel penelitian ini adalah FEM. 
Tabel 2. Hasil Estimasi Model

\begin{tabular}{ccccccc}
\hline \multirow{2}{*}{ Variabel } & \multicolumn{2}{c}{ Common Effect } & \multicolumn{2}{c}{ Fixed Effect } & \multicolumn{2}{c}{ Random Effect } \\
\cline { 2 - 7 } & t-statistik & prob & t-statistik & prob & t-statistik & prob \\
\hline LOG(ROA) & -8.617018 & 0.0000 & -8.084709 & 0.0000 & -9.861725 & 0.0000 \\
LOG(DAR) & -0.701628 & 0.4834 & 3.163435 & 0.0017 & -0.341266 & 0.7331 \\
LOG(SIZE) & 1.970214 & 0.0497 & 0.733200 & 0.4641 & 2.109664 & 0.0357 \\
LOG(KA) & -0.338307 & 0.7354 & 2.358957 & 0.0190 & -0.150242 & 0.8807 \\
LOG(KE) & 3.918818 & 0.0001 & 4.322944 & 0.0000 & 4.569688 & 0.0000 \\
\hline
\end{tabular}

Tabel 3. Uji Chow

\begin{tabular}{lcrc}
\hline \multicolumn{1}{c}{ Effects Test } & Statistic & d.f & Prob \\
\hline Cross-section F & 1.239741 & $(54,270)$ & $0.0000^{*}$ \\
\hline *Alpha $(\mathrm{a})<0.05$ & & &
\end{tabular}

Tabel 4 Uji Hausman

\begin{tabular}{|c|c|c|c|}
\hline Test Summary & Chi-Sq. Statistic & Chi-Sq d. f & Prob \\
\hline Cross-section random & 57.631077 & 5 & $0.0000^{*}$ \\
\hline
\end{tabular}

\section{Analisis Regresi Data Panel}

Dari tabel 5 terlihat bahwa Nilai F-statistic 0.000 lebih kecil dari tingkat signifikansi alpha (a) $(0.000$ $<0.05)$. artinya bahwa model regresi dalam penelitian ini signifikan, dengan kata lain terdapat bukti kuat untuk menunjukam model regresi yang dapat memprediksi variabel tax avoidance. Tabel 5 juga menunjukan nilai Adjusted R-square sebesar 0.813, yang artinya hasil penelitian ini menunjukan bahwa tax avoidance dapat dijelaskan oleh variabel independent (ROA, DAR, SIZE, KA dan $\mathrm{KE}$ ) dalam model regresi sebesar $81,3 \%$, selebihnya yaitu $18,7 \%$ dijelaskan oleh variabel lain diluar model penelitian ini.
Dari hasil pengujian terhadap semua variavel independent (ROA, DAR, SIZE, KA, KE) terhadap variabel dependen (TA) yang disajikan pada tabel 5 untuk variabel Profitabilitas (ROA) diperoleh nilai Prob kurang dari tingkat signifikansi alpha (a) $\quad 0.000$ $<0.05)$ dan nilai Coefficient negatif, maka $\mathrm{H}_{1}$ diterima artinya bahwa secara empiris profitabilitas (ROA) berpengaruh negatif signifikan terhadap Tax avoidance. Nilai koefesien ROA yang negatif menunjukan bukti empiris semakin tinggi profitabilitas perusahaan maka semakin rendah upaya perusahaan untuk melakukan tax avoidance. 
Tabel 5. Hasil Regresi Data Panel dengan variabel dependen Tax avoidance (obs: 330)

\begin{tabular}{lrrr}
\hline Variabel & Coefficient & \multicolumn{1}{c}{ Prob. } & \multicolumn{1}{c}{ Hasil } \\
\hline C & -2.093520 & & \\
LOG(ROA) & -0.401506 & $0.0000^{* *}$ & Mendukung \\
LOG(DAR) & 0.093077 & $0.0017^{* *}$ & Mendukung \\
LOG(SIZE) & 0.603884 & 0.4641 & Tidak Mendukung \\
LOG(KA) & 0.194863 & $0.0190^{*}$ & Mendukung \\
LOG(KE) & 0.228501 & $0.0000^{* *}$ & Mendukung \\
R Square & 0.846887 & & \\
Adjusted R Square & 0.813428 & & \\
Prob (F-statistic) & $0.000000^{* *}$ & & \\
& & & \\
\hline
\end{tabular}

Keterangan:

* Alpha (a)<0.05

** alpha $(\mathrm{a})<0.01$

Seperti dikemukakan Slemrod \& Yitzhaki (2002) bahwa perusahaan yang mempunyai profitabilitas tinggi cenderung akan melaporkan pajaknya dengan jujur daripada perusahaan dengan profitabilitas rendah. Perusahaan dengan profitabilitas rendah pada umumnya mengalami kesulitan keuangan (financial difficulty) dan cenderung akan melakukan ketidakpatuhan pajak.

Perusahaan dengan laba yang besar mampu untuk melakukan pembayaran pajak, bahkan dengan profit yang tinggi perusahaan dengan mudahnya melakukan praktik pengaturan laba (Hidayat, 2018). Perusahaan yang memiliki profitabilitas tinggi memiliki kesempatan untuk memposisikan diri dalam tax planning yang dapat mengurangi jumlah beban kewajiban perpajakan (Chen dkk., 2010). Perusahaan yang memiliki perencanaan pajak yang baik maka akan memperoleh pajak yang optimal, sehingga menurunya kecenderungan perusahaan untuk melakukan tax avoidance (Prakosa, 2014).

Hasil penelitian ini sejalan dengan penelitian sebelumnya yang dilakukan oleh Syuhada dkk. (2019), Handayani (2018), dan Susanti (2018), namun bertentangan dengan penelitian yang dilakukan oleh Budiasih \& Amani (2019) dan Tiala dkk. (2019) yang menunjukan bahwa profitabilitas tidak berpengaruh terhadap tax avoidance.

Untuk hasil pengujian terhadap variabel leverage (DAR) diperoleh nilai Probabilitas kurang dari tingkat signifikansi alpha (a) $(0.0017<0.05)$ dan nilai Coefficient positif, maka $\mathrm{H}_{1}$ diterima artinya bahwa leverage (DAR) berpengaruh positif terhadap tax avoidance. 
Semakin tinggi tingkat hutang suatu perusahaan maka pihak manajemen akan lebih konservatif dalam melakukan pelaporan keuangan atau operasional perusahaan terutama pelaporan pajak perusahaan. Pihak manajemen akan lebih berhati-hati dan tidak akan mengambil resiko yang tinggi untuk melakukan aktivitas tax avoidance guna menekan beban pajaknya. Sehingga dengan hutang yang digunakan perusaha dalam jumlah yang besar dan terus meingkat maka potensi perusahaan untuk melakukan pengindaran pajak semakin meningkat untuk menghidari kerugian bagi perusahaan melalui pemanfaatan hutang yang optimal.

Penggunaan dana yang berasal dari hutang akan meningkatkan risiko perusahaan apabila laba yang diperoleh perusahaan lebih kecil dari biaya bunga. sehingga leverage yang tinggi akan meningkatkan biaya bunga diiringi dengan menurunnya laba sehingga pajak yang dibayarkan pun akan lebih kecil, namun perusahaan juga bisa tidak memanfaatkan utang untuk mengurangi beban pajak tetapi benarbenar untuk membiayai kegitan operasional perusahaan untuk memaksimalkan laba perusahaan yang akan berdampak terhadap meningkatnya pajak perusahaann yang dibayarkan. Dimana hasil penelitian ini sejalan dengan Pitaloka \& Merkusiwati (2019) dan Barli (2018), dan kontradiktif dengan hasil penelitian Budiasih \& Amani (2019), Handayani (2018), dan Susanti (2018) yang menunjukan bahwa leverage berpengaruh terhadap tax avoidance.

Berdasarkan hasil uji variabel Ukuran perusahaan (SIZE) terhadap Tax avoidance (TA) diperoleh nilai Probabilitas lebih dari tingkat signifikansi alpha (a) $(0.4641>0.05)$ dan nilai Coefficient bernilai positif, maka $\mathrm{H}_{1}$ ditolak artinya bahwa Ukuran perusahaan (SIZE) tidak berpengaruh terhadap tax avoidance.

Temuan empirias menunjukan bahwa Ukuran perusahaan yang dinilai dari total aset yang dimiliki perusahaan tidak mempengaruhi perilaku manajemen perusahaan terhadap tax avoidance. akan tetapi biasanya perusahaan yang ukurannya semakin besar semakin besar pula aset perusahaan yang dimilikinya, sehingga biaya operasional dan perusahaan meningkat sehingga perusahaan lebih cenderung melakukan upaya tax avoidance. Dengan kata lain perusahaan akan lebih menghemat dalam melakukan pembayaran pajak, dan biaya yang dikeluarkan oleh perusahaan akan semakin kecil (Fitria, 2018) 


\begin{abstract}
Penelitian ini dimungkinkan perusahaan tidak melakukan perencanaan pajak karena adanya batasan berupa kemungkinan menjadi perhatian dan sasaran dari keputusan regulator dalam hal ini pemerintah (Prakosa, 2014), karena umumnya perusahaan berskala besar
\end{abstract} memiliki asset yang cukup besar, yang dapat dimanfaatkan dalam kegiatan pendanaan dan aktifitas operasional perusahaan. Dalam hal ini membayar pajak merupakan kewajiban perusahaan selaku wajib pajak badan. Sehingga Besar kecilnya perusahaan menjadi fokus perhatian fiskus, dan umumnya perusahaan dengan skala besar akan mendapat perhatian lebih besar dari fiscus, karena memiliki potensi untuk dikenai pajak lebih besar sesuai dengan aturan yang berlaku. Berdasarkan temuan empiris penelitian ini sejalan dengan Barli (2018) dan Susanti (2018), namun bertolak belakang dengan studi Budiasih \& Amani (2019), Fitria (2018), dan Handayani (2018) yang menunjukan bukti empiris bahwa Ukuran perusahaan berpengaruh positif signifikan terhadap tax avoidance.

Berdasarkan hasil uji hipotesis terhadap Komite Audit (KA) terhadap Tax avoidance (TA) pada tabel 5 diperoleh nilai Probabilitas kurang dari tingkat signifikansi alpha (a) $(0.0190<0.05)$ dan nilai Coefficient bernilai positif, maka $\mathrm{H}_{1}$ diterima artinya bahwa Komite Audit (KA) memiliki pengaruh significan terhadap tax avoidance. Koefesien bernilai fositif hal ini menunjukan bahwa apabila komite audit yang dimiliki perusahaan semakin bertambah, maka upaya pengindaran pajak yang dilakukan oleh perusahaan semakin meningkat.

Tax avoidance yang dilakukan perusahaan salah satunya adalah untuk memperkecil beban pajak yang dibayarkan perusahaan, Peran dewan komisaris melalui komite audit dalam upaya mengawasi kegiatan operasional seperti perencanaan pajak yang dilakukan manajamen begitu besar, namun tidak sedikit peran dewan komisaris melakukan penyalahgunaan wewenang dalam hal pengawasan perencanaan pajak yang dilakukan manajemen untuk memperkecil beban pajak terhadap laba perusahaan.

Untuk pembentukan struktur dan pemilihan personil komite audit merupakan tanggungjawab dewan komisaris. Sehingga dewan komisharis wajib menentukan batas minimal jumlah personil komite audit yang ditetapkan sebagaimana regulasi yang berlaku. Apabila perusahaan hanya sampai pada ketaatan regulasi, 
namun belum sampai benar-benar melaksanakan prinsip yang diemban GCG dengan menerapkan segala prinsip yang berlaku sesuai dengan pedoman GCG diharapkan dapat memperkecil tindakan-tindakan yang merugikan berbagai pihak, khususnya tax avoidance. (Mulyani dkk., 2018). Penelitian ini sejalan dengan Pitaloka \& Merkusiwati (2019), Munawaroh \& Sari (2019), Tiala dkk. (2019), dan Mulyani dkk. (2018) yang memperoleh bukti empiris bahwa komite audit berpengaruh terhadap tax avoidance.

Berdasarkan hasil uji hipotesis terhadap Karakteristik eksekutif (KE) terhadap Tax avoidance (TA) pada tabel 5 diperoleh nilai Probabilitas kurang dari tingkat signifikansi alpha (a) $(0.0000<0.05)$ dan nilai Coefficient bernilai positif, maka $\mathrm{H}_{1}$ diterima artinya bahwa Karakteristik eksekutif (KE) memiliki pengaruh signifikan terhadap tax avoidance. Koefesien bernilai positif hal ini menunjukan bahwa apabila Karakteristik eksekutif yang dimiliki para eksekutif semakin meningkat, maka upaya pengindaran pajak yang dilakukan oleh perusahaan semakin meningkat. Penelitian ini sejalan dengan Dyreng et al. (2010) yang menunjukkan bahwa secara indivudu eksekutif memainkan peran penting dalam menentukan tingkat tax avoidance yang dilakukan perusahaan, sesuai dengan karakteristik perusahaan.

Para Eksekutif memiliki dua karakteristik dalam mengambil risiko yaitu risk taker dan risk averse. Bersifat risk taker artinya bawah para ekseuktif akan lebih berani untuk mengambil resiko dalam berbisnis, dengan alasan bahwa semakin tinggi resiko yang diambil akan semakin tinggi keuntungan yang diperoleh. Seperti Banyaknya keuntungan yang ditawarkan diantaranya Kekayaan, Bonus, penghasilan tinggi, kenaikan jabatan dan pemberian wewenang atau kekuasaan menjadi motivasi tersendiri bagi para eksekutif menjadi semakin bersifat risk taker (MacCrimmon \& Wehrung, 1990); (Low, 2009). Karakter eksekutif yang bersifat risk taker atau berani mengambil risiko dapat meningkatkan tindakan tax avoidance. hal ini dikarenakan keputusan eksekutif ingin menjaga kepentingan pemegang saham dengan meningkatkan laba perusahaan semaksimal mungkin. Meskipun tindakan tersebut akan merugikan pemerintah. Jadi, dapat disimpulkan bahwa eksekutif tersebut bersifat risk taker sehingga eksekutif memutuskan untuk berupaya untuk melakukan tax avoidance yang disebabkan adanya motif dan faktor lainnya. Sehingga penelitian ini sejalan dengan Afriyanti dkk. (2019); 
Pitaloka \& Merkusiwati (2019); Praptidewi \& Sukartha (2016); Butje \& Tjondro (2014); dan Dyreng dkk. (2010).

\section{KESIMPULAN, IMPLIKASI DAN KETERBATASAN PENELITIAN}

Penelitian ini menggunakan variable profitabilitas, leverage, ukuran perusahaan, komite audit, dan karaketeristik perusahaan. Tehadap 55 Perusahaan Manufaktur yang listing di BEI dalam kurun waktu 2014 hingga 2019 untuk menguji apakah berpengaruh pada tax avoidance perusahaan. Hasil penelitian menunjukkan bahwa profitabilitas berpengaruh negatif signifikan terhadap Tax Avoidance. sehingga semakin tinggi profitabilitas perusahaan maka semakin rendah upaya perusahaan untuk melakukan tax avoidance, kemudian leverage menunjukan pengaruh positif signifikan terhadap tax avoidance, yang artinya bahwa semakin tinggi tingkat hutang suatu perusahaan maka pihak manajemen akan lebih konservatif dalam melakukan pelaporan keuangan atau operasional perusahaan terutama pelaporan pajak perusahaan. selanjutnya untuk variable Ukuran perusahaan tidak berpengaruh terhadap tax avoidance. Artinya bahwa temuan empiris menunjukan bahwa Ukuran perusahaan yang dinilai dari total aset yang dimiliki perusahaan tidak mempengaruhi perilaku manajemen perusahaan terhadap tax avoidance. Komite Audit memiliki pengaruh positif signifikan terhadap tax avoidance. hal ini menunjukan bahwa apabila komite audit yang dimiliki perusahaan semakin bertambah, maka upaya pengindaran pajak yang dilakukan oleh perusahaan semakin meningkat. dan Karakteristik eksekutif memiliki pengaruh positif signifikan terhadap tax avoidance. hal ini menunjukan bahwa peran eksekutif memainkan peran penting dalam menentukan tingkat tax avoidance yang dilakukan perusahaan.

Penelitian ini memiliki keterbatasan diantaranya Penelitian hanya fokus terhadap perusahaan manufaktur yang listing di BEI, sehingga tidak semua perusahaan diajadikan obsevasi penelitian, kemudian disarankan bagi penelitian selanjutnya agar memperluas sektor perusahaan yang menjadi objek penelitian seperti Perusahaan BUMN, Perbankan dan penelitian selanjutnya juga dapat mengembangkan metode penelitian dengan menggunakan pendekatan kualitatif dan Mixed Method. 


\section{REFERENSI}

Afriyanti, S. A., Sugiarti, \& Hariyanti, W. (2019). Pengaruh Karakter Eksekutif dan Dimensi Tata Kelola Perusahaan terhadap Penghindaran Pajak. Journal of Islamic Finance and Accounting, 2(1), 1-13.

Anderson, R. C., \& Reeb, D. M. (2003). Founding-Family Ownership and Firm Performance: Evidence from the S\&amp;P 500. The Journal of Finance, 58(3), 1301-1328. https: / /doi.org/10.1111/15406261.00567

Andriyanto, A. B., Wahyudi, S., \& Demi, P. I. (2015). Analisis Pengaruh Profitabilitas, Firm Size, dan Sales Growth terhadap Nilai Perusahaan dengan Dividend Payout Ratio Sebagai Variabel Intervening (Studi Pada Perusahaan Manufaktur yang Listing di BEI 2010-2013). Universitas Dipenogoro.

Barli, H. (2018). PENGARUH LEVERAGE DAN FIRM SIZE TERHADAP PENGHINDARAN PAJAK (Studi Empiris pada Perusahaan sektor Property, Real Estate dan Building Construction yang Terdaftar di Bursa Efek Indonesia Periode Tahun 20132017). Jurnal Ilmiah Akuntansi Universitas Pamulang, 6(2), 223238.

Bhuiyan Mohammad Zahid Hossain. (2012). Tax Evasion and Avoidance Practices in Some Selected Corporate Firms of Bangladesh. World Journal of Sosial Sciences, 2(7), 150-156.

Blaufus, K., Hundsdoerfer, J., Jacob, M., \& Sünwoldt, M. (2016). Does legality matter? The case of tax avoidance and evasion. Journal of Economic Behavior \& Organization, 127, 182-206. https://doi.org/10.1016/j.jebo.2 016.04.002

Brigham, E. F., \& Houston, J. F. (2019). Fundamentals of Financial Management 15 Edition (15th ed.). Cengage Learning.

Budiasih, Y., \& Amani, A. (2019). Faktor-Faktor Yang Berpengaruh Terhadap Tax Avoidance Perusahaan Manufaktur Sub Sektor Makanan Dan Minuman Terdaftar DI BEI Tahun 20132017. Jurnal Penelitian Manajemen, 1(1), 74-85.

Butje, S., \& Tjondro, E. (2014). Pengaruh Karakteristik Eksekutif dan Koneksi Politik Terhadap Tax Avoidance. Tax \& Accounting Review, 4(2), 1-9.

Carolina, V., Maria, N., \& Debbianita. (2014). Karakteristik Eksekutif Terhadap Tax Avoidance Dengan Leverage Sebagai Variabel Intervening. Jurnal Keuangan Dan Perbankan, 18(3), 409-419.

Chen, S., Chen, X., Cheng, Q., \& Shevlin, T. (2010). Are family firms more tax aggressive than non-family firms? Journal of Financial Economics, 95(1), 4161.

https://doi.org/10.1016/j.jfineco .2009.02.003

CNN Indonesia. (2016). DJP Bongkar Motif 2.000 Perusahaan yang Kemplang Pajak. CNN Indonesia.

Dewi, N. N. K., \& Jati, I. K. (2014). Karakteristik Eksekutif. E-Jurnal Akuntansi Udayana, 6(2), 249260.

Dewinta, I. A. R., \& Setiawan, P. E. (2016). Pengaruh Ukuran Perusahaan, Umur Perusahaan, Profitabilitas, Leverage, Dan Pertumbuhan Penjualan Terhadap Tax Avoidance. E-Jurnal 
Akuntansi Universitas Udayana, 14(3), 1584-1615.

Diantari, P. R., \& Ulupui, I. A. (2016). Pengaruh Komite Audit, Proporsi Komisaris Independen, Dan Proporsi Kepemilikan Institusional Terhadap Tax Avoidance. E-Jurnal Akuntansi, 16(1), 702-732.

Undang-Undang Nomor 36 Tahun 2008 tentang Perubahan Keempat atas Undang-Undang Nomor 7 Tahun 1983 tentang Pajak Penghasilan, Pub. L. No. 36 (2008).

Dogan, M. (2013). Does firm size affect the firm profitability? Evidence from Turkey. Research Journal of Finance and Accounting, 4(4), 5360.

Dyreng, S. D., Hanlon, M., \& Maydew, E. L. (2008). Long-Run Corporate Tax Avoidance. The Accounting Review, 83(1), 61-82. https://doi.org/10.2308/accr.20 08.83.1.61

Dyreng, S. D., Hanlon, M., \& Maydew, E. L. (2010). The Effects of Executives on Corporate Tax Avoidance. The Accounting Review, 85(4), 1163-1189. https: / /doi.org/ 10.2308/accr.20 10.85.4.1163

Fitria, G. N. (2018). Pengaruh Kepemilikan Institusional, Komisaris Independen, Karakter Eksekutif Dan Size Terhadap Tax Avoidance. Jurnal Profita: Komunikasi Ilmiah Akuntansi Dan Perpajakan, 11(3), 438-451.

Ghozali, I., \& Ratmono, D. (2017). Analisis Multivariat dan Ekonometrika (Teori, Konsep, dan Aplikasi dengan Eviews 10) (2nd ed.). Fakultas Ekonomi dan Bisnis Universitas Dipenogoro.
Hanafi, U., \& Harto, P. (2014). Analisis Pengaruh Kompensasi Eksekutif, Kepemilikan Saham Eksekutif dan Preferensi Risiko Eksekutif Terhadap Penghindaran Pajak Perusahaan. Diponegoro Journal of Accounting, 3(2), 1-11.

Handayani, R. (2018). Pengaruh Return on Assets (ROA), Leverage dan Ukuran Perusahaan Terhadap Tax Avoidance Pada Perusahaan Perbankan yang Listing di BEI Periode Tahun 2012-2015. Jurnal Akuntansi Maranatha, 10(1), 72-84. https://doi.org/10.28932/jam.v1 0i1.930

Hanum, H. H., \& Zulaika. (2013). Pengaruh Karakteristik Corporate Governance Terhadap Effective Tax Rate (Studi Empiris Pada Bumn Yang Terdaftar Di Bei 2009-2011). Diponegoro Journal Of Accounting, 2(2), 201-210.

Hasan, I., Hoi, C.-K. S., Wu, Q., \& Zhang, H. (2017). Does Social Capital Matter in Corporate Decisions? Evidence from Corporate Tax Avoidance. Journal of Accounting Research, 55(3), 629-668. https:/ /doi.org/10.1111/1475679X.12159

Hidayat, W. W. (2018). Pengaruh Profitabilitas, Leverage Dan Pertumbuhan Penjualan Terhadap Penghindaran Pajak. Jurnal Riset Manajemen Dan Bisnis (JRMB) Fakultas Ekonomi UNIAT, 3(1), 19-26. https://doi.org/10.36226/jrmb.v $3 \mathrm{i} 1.82$

Jensen, M. C., \& Meckling, W. H. (1976). Theory of the firm: Managerial Behavior, Agency Costs and Ownership Structure. Journal of Financial Economics, 13 , 305-360. 
https: / /doi.org/10.1016/0304405X(76)90026-X

Kay, J. (1980). The Anatomy Of Tax Avoidance. Proceeding of the 31st Symposium of the Colstor Research Society, 135-148.

Kementerian Keuangan Republik Indonesia. (2019). Informasi APBN Kita 2019.

Klein, A. (2002). Audit committee, board of director characteristics, and earnings management. Journal of Accounting and Economics, 33(3), 375-400. https: / /doi.org/10.1016/S01654101(02)00059-9

Lee, J. (2009). Does Size Matter in Firm Performance? Evidence from US Public Firms. International Journal of the Economics of Business, 16(2), 189-203. https: / / doi.org/10.1080/135715 10902917400

Low, A. (2009). Managerial risk-taking behavior and equity-based compensation. Journal of Financial Economics, 92(3), 470490.

https://doi.org/10.1016/j.jfineco .2008.05.004

MacCrimmon, K. R., \& Wehrung, D. A. (1990). Characteristics of Risk Taking Executives. Management Science, 36(4), 422-435. https://doi.org/10.1287/mnsc.3 6.4 .422

Mangoting, Y. (1999). Tax Planning: Sebuah Pengantar Sebagai Alternatif Meminimalkan Pajak. Jurnal Akuntansi Dan Keuangan, 1(1), 43-53.

Mulyani, S., Wijayanti, A., \& Masitoh, E. (2018). Pengaruh Corporate Governance Terhadap Tax Avoidance (Perusahaan Pertambangan yang terdaftar di
BEI). Jurnal Riset Akuntansi Dan Bisnis Airlangga, 3(1), 322-340. https://doi.org/10.31093/jraba.v $3 \mathrm{i} 1.91$

Munawaroh, M., \& Sari, S. P. (2019). Pengaruh Komite Audit, Proporsi Kepemilikan Institusional, Profitabilitas dan Kompensasi Rugi Fiskal Terhadap Penghindaran Pajak. Seminar Nasional \& Call For Paper Seminar Bisnis Magister Manajemen (SAMBIS-2019), 352-367.

Peraturan Otoritas Jasa Keuangan Nomor 55 /POJK.04/2015 Tentang Pembentukan Dan Pedoman Pelaksanaan Kerja Komite Audit. (2015). POJK No. 55/POJK.04/2015 Pembentukan dan Pedoman Pelaksanaan Kerja Komite Audit. Jakarta. Pemerintah Indonesia, 1-14.

Peraturan Pemerintah Nomor 77 Tahun 2013, (2013).

Pitaloka, S., \& Merkusiawati, N. K. L. A. (2019). Pengaruh Profitabilitas, Leverage, Komite Audit, dan Karakter Eksekutif Terhadap Tax Avoidance. E-Jurnal Akuntansi, 27, 1202. https:/ /doi.org/ 10.24843/EJA.2 019.v27.i02.p14

Prakosa, K. B. (2014). Pengaruh profitabilitas, kepemilikan keluarga dan corporate governance terhadap penghindaran pajak di Indonesia. Simposium Nasional Akuntansi XVII, 24-27.

Praptidewi, L., \& Sukartha, I. (2016). Pengaruh Karakteristik Eksekutif Dan Kepemilikan Keluarga Pada Tax Avoidance Perusahaan. EJurnal Akuntansi, 17(1), 426-452.

Puspita, S. R., \& Harto, P. (2014). Pengaruh Tata Kelola Terhadap Penghindaran Pajak. Diponegoro 
Journal of Accounting, 3(2), 1-13.

Putranti, T. M., Jati, W., \& Tambunan, M. R. U. D. (2015). Studi Penghindaran Pajak Kegiatan Jasa Perbankan di Indonesia.

Https: / / Responsibank.Id/.

Putri, T. R. F. (2017). FAKTOR FAKTOR YANG MEMPENGARUHI TAX AVOIDANCE PADA PERUSAHAAN MANUFAKTUR YANG TERDAFTAR DI BURSA EFEK INDONESIA PADA TAHUN 2011-2015. Universitas Negeri Semarang.

Putri, T. R. F., \& Suryarini, T. (2017). Factors Affecting Tax Avoidance on Manufacturing Companies Listed on IDX. Accounting Analysis Journal, 6(3), 407-419.

Slemrod, J., \& Yitzhaki, S. (2002). Tax Avoidance, Evasion, and Administration. In Journal of Public Economics (Vol. 3, Issue 2, pp. 1423-1470).

https://doi.org/10.1016/S15734420(02)80026-X

Stiglitz, J. E. (1985). The General Theory Of Tax Avoidance. National Tax Journal, 38(3), 325338.

Sulistiyanti, U., \& Saputra, A. D. (2020). Determinants of tax avoidance: Evidence from Indonesian mining industry. Journal of Contemporary Accounting, 2(3), 165-174. https://doi.org/10.20885/jca.vol 2.iss3.art5

Surbakti, T. A. V. (2012). Pengaruh Karakteristik Perusahaan Dan Reformasi Perpajakan Terhadap Penghindaran Pajak Di Perusahaan Industri Manufaktur Yang Terdaftar DI Bursa Efek Indonesia Tahun 2008-2010. Universitas Indonesia.
Susanti, C. M. (2018). Pengaruh Konservatisme, Leverage, Profitabilitas, Ukuran Perusahaan Terhadap Tax Avoidance. Jurnal Informasi Perpajakan, Akuntansi, Dan Keuangan Publik, 13(2), 181198.

https://doi.org/10.25105/jipak.v $13 \mathrm{i} 2.5021$

Syuhada, A., Yusnaini, Y., \& Meirawati, E. (2019). PENGARUH GOOD CORPORATE GOVERNANCE DAN PROFITABILITAS TERHADAP TAX AVOIDANCE (STUDI EMPIRIS PADA SEKTOR PERTAMBANGAN YANG TERDAFTAR DI BEI). AKUNTABILITAS, 13(2), 127-140. https://doi.org/10.29259/ja.v13i 2.9515

Tiala, F., Ratnawati, R., \& Rokhman, M. T. N. (2019). Pengaruh Komite Audit, Return On Assets (ROA), Dan Leverage Terhadap Penghindaran Pajak. Jurnal Bisnis Terapan, 3(01), 9. https://doi.org/10.24123/jbt.v3i 01.1980

Tirto.id. (2019). DJP Dalami Dugaan Penghindaran Pajak PT. Adaro Energy. Tirto.Id.

Undang-Undang No. 36 Tahun 2008. (n.d.). Undang-Undang Republik Indonesia Nomor 36 Tahun 2008 Tentang Perubahan Keempat Atas Undang-Undang Nomor 7 Tahun 1983 Tentang Pajak Penghasilan.

www.kontan.co.id. (2019). Tax Justice laporkan Bentoel lakukan penghindaran pajak, Indonesia rugi US\$ 14 juta. Www.Kontan.Co.Id. 